\title{
Norises Rīgā 1919. gada 12.-15. oktobrī kauju laikā ar Bermonta spēkiem: atspoguḷojums Lielbritānijas politiskās misijas vadītāja Stīvena Talentsa ziṇojumos
}

\author{
Events in Riga in October 12-15, 1919 during the Battles with Bermondt Forces: \\ Reflection in Reports of the Head of British Political Mission Stephen Tallents
}

Dokumentus publicēšanai sagatavojis, no ang!u valodas tulkojis un komentējis

Translation and commentaries by

Ëriks Jēkabsons, Dr. hist.

Latvijas Universitātes Vēstures un filozofijas fakultātes

Vēstures un arheoloğijas nodaḷas profesors

Aspazijas bulvāris 5, Rīga, LV-1050

E-pasts: eriks.jekabsons@lu.lv

1919. gada 8. oktobrī sākās Bermonta komandētās vāciski krieviskās Rietumkrievijas armijas uzbrukums Latvijas galvaspilsētā, pirmajās dienās izraisot strauju Latvijas armijas atkāpšanos. Gandrīz tika zaudēta Rìga, un tikai pēdējā brīdī paspēja noorganizēt aizsardzības līniju uz Daugavas. 10. oktobrī Rīgā "valdỉja panikas pazìmes" un "sabiedrïbas padibenes Iekšrīgā sāka dauzit veikalu logus un laupït", ${ }^{1}$ taču 11.-12. oktobrī stāvoklis bija noregulējies, Latvijas armijas vienībām ieņemot stingru aizsardzības līniju gar Daugavu. Tiesa, 12. oktobrī britu un franču karakuǵi saskaņā ar Bermonta armijas pārstāvja ieteikumu un neinformējot par notiekošo savas pilsētā esošās misijas, tika izvesti no Rīgas ostas - tas negatīvi iespaidoja Latvijas armijas karavīru noskaņojumu. 13. oktobrī Latvijas armijas daḷas bez kaujas ieñēma ienaidnieka atstāto Doles salu, bet valdības vadītājs Kārlis Ulmanis ar vairākiem ministriem atgriezās Rīgā no Cēsīm. Šajā pašā dienā ārlietu ministrs Zigfrīds Anna Meierovics devās palīdzības meklējumos uz Lietuvu un Poliju, lai pievienotos tur jau esošajai Jāṇa Zālīša vadītajai delegācijai. 14. oktobrī Latvijas armijas daḷas mēgināja forsēt tiltus, kā arī pāriet Daugavu pie Bolderājas, bet tas neizdevās izrādītās pretestības dēḷ. Britu admirālis Valters Kovans pieprasīja Bermontam izvest karaspēku no Daugavgrīvas cietokšn,a, Ministru prezidents Kārlis Ulmanis personiski apmeklēja ierakumus Peldu ielā Rīgā, gūstot vieglu kontūziju pēdā no Bermonta artilērijas lādiṇa šḳembas. Vēl šajā dienā Vācijas armijas 6. rezerves korpusa komandieris, lielā mērā uzbrukuma Rīgai plāna iniciators Rīdigers fon der Golcs no Jelgavas aizbrauca uz Vāciju, bet viṇa pēctecim 
Magnusam fon Eberhardam vācu karaspēks, kas atradās Zemgalē un Kurzemē un bija iekḷauts Bermonta armijā, atteicās paklausīt. Tāpat Rīgā no Londonas atgriezās Latvijas Pagaidu valdības finanšu ministrs Roberts Erhards, kurš bija mēǵginājis nesekmīgi gūt aizdevumu no britu valdības.

15. oktobrī nesekmīgais Latvijas armijas vienību uzbrukums pāri tiltiem Rīgā tika atkārtots vēlreiz, lai novērstu ienaidnieka uzmanību no uzbrukuma mērḳa Bolderājā. Šoreiz uz tiltiem tika ciesti smagi zaudējumi. Toties, pateicoties tam, ka iesaistījās sabiedrotie, un viņu karakug̣u artilērijas atbalstam, 9. Rēzeknes kājnieku pulka desantam kuğīšos pāri Daugavai pie Bolderājas izdevās ieņemt Daugavgrīvas cietoksni un Bolderājas miestu. ${ }^{2}$

Šeit publicēti divi Lielbritānijas Politiskās misijas vadītāja Stīvena Talentsa ${ }^{3}$ ziṇojumi ārlietu ministram Džordžam Kērzonam (George Curzon), kuri aptver norises Latvijas galvaspilsētā no 1919. gada 12. līdz 15. oktobrim. Ziņojumi veido turpinājumu žurnāla iepriekšējā numurā publicētajam S. Talentsa ziņojumam, kas aptver notikumus laikā no 9. līdz 11. oktobrim (sk.: Latvijas Universitātes Žurnāls. Vēsture 2018, Nr. 6, 175.-187. lpp.).

S. Talentsa ziņojumos ietvertā informācija būtiski paplašina Latvijas historiogrāfijā pastāvošo viedokli par norisēm aplūkojamajās dienās. To orig̣ināli atrodas Lielbritānijas Nacionālajā arhīvā Londonā Ārlietu ministrijas dokumentu kolekcijā. ${ }^{4}$ S. Talentss apskata pilsētā valdošo situāciju, atstāsta savas sarunas par aktuālajiem jautājumiem ar Latvijas valdības un armijas virspavēlniecības pārstāvjiem, citu sabiedroto misiju vadību šajā laikā, kā arī britu misijas darbību u. c. jautājumus.

Publikācijā sākotnēji sniegts dokumenta oriǵinālteksts angḷu valodā, pēc tam - tulkojums latviešu valodā ar komentāriem un skaidrojumiem.

\section{Document No. 1}

Report of events in Riga, October $12^{\text {th }}$ to $13^{\text {th }}, 1919$

\section{October $12^{\text {th }}$.}

1. At about 10:30 I called on General Simonsen and Colonel Kalnin at Headquarters Staff, and tell [sic] them that in accordance with a decision taken by General Burt with regard of his own Mission, I proposed to embark the same evening those members of my Mission who were not required for immediate work. I explained that a sufficient staff was remaining in Riga, and that I had come to them personally so that there should be no misunderstanding about what I was doing. Colonel Kalnin looked much overwrought at this interview, and upon my telling General Simonsen that he could, of course, count on my offering any help I could give, but that I feared the Political Mission could do little for him at the moment, Colonel Kalnin let fall a bitter aside in Lettish to the effect that help from English ought to have come long ago.

2. At lunch time Mr Ulmanis arrived with Mr Meierovicz and asked anxiously what the Allies were doing about Bermondt's attack. We could only tell him that we had no news of any kind, except that a blockade of German ships had been imposed in the Baltic. He told me that negotiations with the Estonians for military co-operation were proceeding. The Estonians asked for Walk and for a single command under General Laidoner. Certain difficulties still remain but he expected that these would be settled. I had been hailed 
in the streets that morning by General Pödder and Colonel Reek, old acquaintances in the Estonian army, and these officers came to call on me after lunch. They explained that they had come to Riga in spite of strict orders to the contrary and impressed on me that theirs was an unofficial visit. I left them talking with Mr Ulmanis.

3. At this point we received news from the ships by telephone that they were moving out in response to a request made by a Russian officer who had boarded them the same morning. The account given of this incident so surprised General Burt and myself that we decided to visit the S.N.O. in person.

4. On our way to the river, we called on Colonel Ryan of the American Red Cross, who had that morning crossed the bridge under a flag of truce. He had come to the bridge-head accompanied by Colonel Grove, but the latter, as a military officer, had not been allowed to cross, whereas Colonel Ryan, as a Red Cross representative, had been sent forward. He had climbed across a ladder where the centre part of the bridge has been raised and was evidently tired of adventures, for though he had arranged to go back after three days, he expressed his intention of staying in Riga. He spoke of seeing some heavy artillery on the Mitau road drawn by six horses to a gun. The Germans had spoken to him of 700 casualities at all, of which 250 were killed. They had said that their worst losses were due to encounter between two German companies which mistook each other for Letts and were finally wiped out after bitter fighting by a Lettish armoured train which ran in between them. Every German to whom he had spoken expressed his determination not to return to Germany. They were going, they said, to make a place for themselves in Russia. If they got driven back to Germany, they would there take by force whatever they needed. In the meantime, conflicting orders were being given by German and Russian officers, the former being inclined to take command and the latter to resent their assumption of authority in the operations. The Iron Division, he said, were anxious to take Riga but the Russians were against a violent attack on the town.

5. Colonel Ryan had seen in Mitau with Colonel Grove, Count Pahlen, the Balt President of the new Council which Bermondt had appointed. Pahlen had expressed his regret at not having had an opportunity of explaining his position to me. He was inclined to apologise to Colonel Ryan for the company in which he now found himself, and urged that the best solution was for the Allies to father the whole adventure and direct it along reasonable lines. It is interesting to note that Pahlen was until lately regarded as one of the Balts who were especially symphatetic to the Letts. When $\mathrm{Mr}$ Tschakste, the Lettish President of the People's Council, Complained to Baron Fircks of the inclusion of Brümmer as a Balt representative in the People's Council, he at the same time suggested that Pahlen ought to have been chosen instead for the vacancy. I am told that in South Lettland the peasants are bolshevistically inclined - largely owing to the continued German occupation - and that the propertied Letts in consequence tend to join forces with Balts. The inclusion of Letts in Bermondt's new Council has probably been made possible by this fact.

6. I was handed by Colonel Ryan a note from Bermondt and his Council, of which a copy is attached to this dispatch as appendix 1 .

7. Colonel Ryan also handed General Burt a protest from General von der Goltz with regard to the treatment of certain Germans in Libau. This note aroused some suspicion that von der Goltz had designs on that town. 
8. I was given the same afternoon a translated copy of an intercepted telegram of October $12^{\text {th }}$ from Bermondt to Yudenich. It read as follows: ---

[...]

9. On leaving Colonel Ryan, General Burt and I motored down to the landing stage by the Provodnik factory, where we had arranged for a motorboat to meet us. We went off to H.M.S. Abdiel and there saw Major Keenan and, for a time, Captain Curtiss, the S.N.O. We were principally occupied in discussing with them two incidents:

10. Some misunderstanding had arisen out of a telephone message received by Major Greenslade from Major Keenan that the British ships were protecting the Lettish right flank, would shoot any aeroplane that come within range, and would prevent troops from crossing the river. We ascertained from Major Keenan that the destroyers had the previous day been arranged in positions which enabled them to watch the Lettish right flank, but that no definite decision had been taken as to action in case any part of the Russian troops attempted to cross. I suggested to major Keenan that this arrangement hardly constituted "protection" in the military sense. General Burt said that he must at once see the Lettish Headquarters Staff on his return to Riga and explain the mistake. This he subsequently did.

11. We also discussed with major Keenan the incident of that morning which had resulted in capt. Curtiss's decision to move the Allied destroyers down the river. This operation took place while we were on board H.M.S. Abdiel, and Capt. Curtiss, who was superintending the navigation, was therefore not present during most of our discussion. I attach as appendix 2 copy of a note of this incident given to me on the following day by the Military Mission. It appeared to me, and, I understood, to General Burt, from Major Keenan's account that Baron von Rönne had been treated with excessive consideration, and that the decision to move the ships down the river on the suggestion of a Russian battery commander, acting without his superior's orders, was likely to be most damaging to British prestige.

12. In agreement with General Burt, I drafted the following telegram which the S.N.O. undertook to have dispatched: ---

"Following for Troopers Astoria Foreign Office from General Burt Colonel Tallents: Following information is vitally required (1) What steps are Allies taking in Bermondt's attack (2) Are his forces regarded as outlaws or breaking the armistice (3) Lettish Government on the ground that they are doing work of the Allies urgently request bombardment by ships for purposes of moral support. Can permission been [sic] granted?"

We sent this telegram because we learned that the S.N.O., like ourselves, was entirely without information upon the points which it raised, except that he had received an order to be strictly neutral.

13. We embarked on the night of October $12^{\text {th }}$ the following officers from the Political Mission: ---

Lt.-Commander Stoddart (in charge)

Mr Hansen (second in command)

Mr Berry

Capt. Brodie

Mr Malcolm

Mr Ellis 
Capt. Farrow

Mr Richards

Sergt. Worall

Commander Stoddart and Mr Berry were instructed to proceed to Reval by sea at the first opportunity for the purpose of bringing the accounts of that Branch of the Mission up to date, Capt. Farrow, who was sick, was to be evacuated to England at the first convenient opportunity for discharge from the service of this Mission. Those left on the staff of the Mission ashore were as follows: ---

Lt.-Colonel Tallents

Capt. Dewhurst

Capt. Sir Warrender

Mr L. Collas

Mr Hampson

Mr Wilson

Corp. Warren

Mr Student

"Cristopher" (an English-speaking Lett)

There were also embarked the following Danish and Dutch subjects: ---

Danish

$\underline{\text { Dutch }}$

Mr J. McBride

Mr Heitbroek

Mr M. Ragan

Mr Bosschart

Mr A. Brown

Mr Speyer

Mr F. Herskind

Mr Levie

Mr Maters

Mr Marcus

Mr Claude

Mr Vandenberg

Mr Van Messel

I had observed that one of the men recommended for embarkment by the Danish Consul was an agent of the Baltic Bank, and I asked Major Keenan before leaving the ships to secure that all these alien refugees were kept strictly on board and that there should be a considerable delay, if possible, in their arrival at their destinations.

\section{October $13^{\text {th }}$.}

14. At 3 a.m. Major Greenslade woke me with a note of a telephone message from Major Keenan. This indicated that S.N.O. Baltic desired to know, in case of bombardment by the ships being practicable, whether the Allied Missions could be embarked. I got up and drafted a suggested reply for dispatch by S.N.O. Riga, and asked Major Greenslade to suggest to General Burt that he should propose this answer to the French and American Missions in the morning. The telegram was ultimately sent as drafted in the following terms, the words in brackets being added by General Burt: ---

"Missions unanimously desire Allied bombardment for moral effect on Lett and Hun. For same purpose they insist on staying in Riga - on their own responsibility if necessary.

(May a naval officer come here immediately for full details of action required)" 
15. I was shown the same morning the copy of a telegram which General Burt and Colonel Du Parquet had decided to send to the ships for dispatch to S.N.O. Baltic. This telegram ran as follows: ---

"General Burt and Colonel Du Parquet request you to send to the O.[fficer] C. [ommanding] forces at Mitau and Dunamünde that they should withdraw their guns and troops at once from the positions at and about Dunamünde as these constitute a danger to the Allied vessels which have distinct orders to remain in the river.

If this order is not carried out by the time that S.N.O. Riga orders, it will be necessary for the Allied ships to take action to enforce this.

Signed ALFRED BURT, Brig.Gen.

DU PARQUET, Lt-Col, Chief Mission Français"

16. I learned this morning that Mr Meierowicz, the Foreign Minister, had left the night before for Warsaw.

17. Numerous persons of British, Danish, Norwegian, Dutch, Russian, Polish, Persian, Checho-Slovakian and other nationalities visited the Mission during the morning to ask for protection in various forms. I accordingly visited the deputy for the Minister for Foreign Affairs, Mr Albat, and later Capt. Dambalkan, the Town Commandant with a view to agreeing systematic arrangements. Our Lettish liaison officer, Mr Student, was given a pass to conduct parties of refugees to the landing stage. We undertook to provide the Commandatur each day with a list of those evacuated and to refer any doubtful cases to the Commandant for his opinion. The Lettish authorities, on their part, agreed that I should evacuate any nationals of other countries that thought fit. Their main object was to prevent deserters from escaping. We sent on board the ships, leaving the landing stage at 7 o'clock the same evening, the following party: ---
Mr Lushington (British)
Mr Rumsey (British)
Mr F. Vrancken (Belgian)
Miss F. Wagner (Lett)
Mr C. F. Plaht, Mrs Plaht \&
Mr W. Endel (Dutch)
Daughter (Russian)
Mr W. D. Addison (Brit.)
Miss K. Sonnenberg (Lettish)
Mrs Gray (Russian)
Mr H. B. Bruun (Danish)
Mr Onnen (Dutch)
Mr J. F. Jacobsen (Dutch)
Mr E. Ammende (Russ.)

Each member of this party was required to sign the following declaration: ---

"I understand that no guarantee of embarkation is given, no responsibility is taken for the safety of person or property, no particular destination can be promised, and once embarked, no one will be allowed to disembark, at any rate till further notice."

18. About 3 p.m. I was called to the telephone office to speak on Hughes machine with Reval. I found that Major Bevin, of the Reval Military Mission was at the other end of the line, having been called as a result of an arrangement intended to take effect the day before. I told him I believed that the Riga Military Mission wanted to know what supplies of arms they were sending to Letts. He replied that the ss. Pyrgos had just arrived with guns of all sorts and that the first consignment of supplies would leave Reval by rail on the evening of October 14. I inquired whether any news had been received of the Allies' action on Bermondt's attack and was told that none had been reached them.

S. G. Tallents Lt-Colonel

BRITISH COMMISSIONER FOR THE BALTIC PROVINCES 


\section{1. dokuments}

\section{Ziņojums par notikumiem Rīgā 1919. gada 12.-13. oktobrī}

\section{2. oktobrī.}

1. Apmēram plkst. 10.30 es apmeklēju genenēli Sīmansonu ${ }^{5}$ un pulkvedi Kalniṇu ${ }^{6}$ Armijas virspavēlnieka štābā un informēju viṇus, ka saskaṇā ar generāḷa Bērta ${ }^{7}$ pieṇemto lēmumu attiecībā uz viṇa misiju tajā pašā vakarā esmu devis rīkojumu uzkāpt uz karakugiem tiem manas misijas locekḷiem, kuri nav nepieciešami neatliekamu darbu veikšanai. Es paskaidroju, ka Rīgā paliek pietiekami daudz darbinieku un ka esmu ieradies pie vin,iem personīgi, lai nerastos nekādi pārpratumi par manu rīcību. Pulkvedis Kalniņš sarunas laikā izskatījās l,oti pārguris, un, kad sacīju ǵenerālim Sīmansonam, ka viņš, protams, var rēķināties ar visu manu iespējamo palīdzību, tomēr es baidos - politiskā misija šajā brīdī viņa labā var izdarìt maz, - pulkvedis Kalniņš ar rūgtumu latviski izmeta - palīdzībai no angliem vajadzēja nākt jau sen atpakaḷ.

2. Pusdienu laikā ieradās Ulmaņa ${ }^{8}$ kungs kopā ar Meierovica ${ }^{9}$ kungu un satraukti jautāja, ko sabiedrotie ir darījuši saistībā ar Bermonta ${ }^{10}$ uzbrukumu. Mēs viṇam varējām vienīgi atbildēt, ka neesam saṇēmuši nekādu informāciju, izņemot ziṇu, ka Baltijas jūrā ieviesta blokāde vācu kuğiem. ${ }^{11}$ Viņš man sacīja, ka turpinājušās sarunas ar igauniem par militāro sadarbību. Igauṇi pieprasījuši Valku un piekrišanu vienotai virspavēlniecībai generāḷa Laidonera vadībā. ${ }^{12}$ Joprojām saglabājas noteiktas grūtības, taču vin,š cer, ka tās tiks atrisinātas. Šorīt uz ielas mani sveicināja ǵgenerālis Peders ${ }^{13}$ un pulkvedis Rēks, ${ }^{14}$ veci paziņas no Igaunijas armijas, un šie virsnieki apciemoja mani pēc pusdienām. Viṇi paskaidroja, ka ieradušies Rīgā, neraugoties uz stingrām pavēlēm to nedarīt, un radīja iespaidu par viṇu vizītes neoficiālo raksturu. Es atstāju viņus sarunājamies ar Ulmaṇa kungu.

3. Tajā brīdī mēs saṇēmām telefonisku ziṇu no kugiem, ka tie aizbrauc, reaǵējot uz kāda krievu virsnieka prasību, - viņš šorìt bija uzkāpis uz klāja. Notikušā apraksts tā pārsteidza ǵenerāli Bērtu un mani, ka mēs nolēmām personiski apmeklēt v[ecāko] j[ūras] v[irsnieku].

4. Pa ceḷam uz upi mēs apmeklējām pulkvedi Raienu ${ }^{15}$ no Amerikas Sarkanā Krusta, kurš tajā rītā bija pārgājis pāri tiltam ar balto karogu. Viņš bija ieradies pie priekštilta kopā ar pulkvedi Grovu, ${ }^{16}$ taču pēdējam kā armijas virsniekam netika ațlauts to šḳērsot, kamēr pulkvedis Raiens kā Sarkanā Krusta pārstāvis tika sūtīts uz priekšu. Viṇš pāri trepēm bija uzrāpies uz paceltās tilta malas tā centrā un acīmredzami bija noguris no piedzīvojumiem, jo, kaut arī nokārtojis savu atgriešanos pēc trijām dienām, pauda gatavību palikt Rīgā. Viņš stāstīja, ka redzējis smago artilēriju uz Jelgavas šosejas, katru lielgabalu vilkuši seši zirgi. Vācieši viṇam stāstījuši par saviem 700 zaudētajiem karavīriem, no kuriem 250 bija krituši. Tie sacīja, ka smagākie zaudējumi viņiem bijuši sadursmē starp divām vācu rotām, kuras viena otru kḷūdaini uzskatījušas par latviešiem, un galu galā pēc sīvas kaujas tās noslaucījusi starp tām iebraukušā latviešu bruṇotā vilciena uguns. Visi vācieši, ar kuriem viņš bija runājis, pauda apṇemšanos neatgriezties Vācijā. Tie sacīja, ka vēlas atrast sev vietu Krievijā. Ja tos nosūtīs atpakal, uz Vāciju, viṇi ar varu varētu paṇemt visu sev vajadzīgo. Pa to laiku vācu un krievu virsnieki bija izdevuši savstarpēji pretrunīgas pavēles, pirmie vēlējās uzṇemties vadību, bet pēdējos aizvainoja vāciešu ambīcijas operācijās. Viņš [Raiens] sacīja, ka Dzelzsdivīzija uztraucoties par Rīgas ien,emšanu, bet krievi esot pret strauju uzbrukumu pilsētai. 
5. Pulkvedis Raiens Jelgavā tikās ar pulkvedi Grovu, grāfu Pālenu17 - vācbaltieti, jaunās, Bermonta ieceltās padomes priekšsēdētāju. Pālens paudis nožēlu, ka viṇam nav iespējams man izskaidrot savu nostāju. Viņš bija gatavs atvainoties pulkvedim Raienam par sabiedrību, kādā viņš tagad atradās, un uzsvēra, ka labākais risinājums sabiedrotajiem būtu uzṇemties aizbildṇa lomu pār visu avantūru un to saprātīgi vadīt. Interesanti, ka Pālens vēl nesen tika uzskatīts par vienu no vācbaltiešiem, kas sevišķi simpatizē latviešiem. Kad Čakstes ${ }^{18}$ kungs, Tautas padomes priekšsēdētājs, sūdzējās baronam Firksam ${ }^{19}$ par Brimmera ${ }^{20}$ kā vācbaltiešu pārstāvja iekḷaušanu Tautas padomē, viņš vienlaikus piedāvāja, ka brīvajā vietā vajadzētu iecelt Pālenu. Man ir teikuši, ka Dienvidlatvijā zemnieki ir noskan,oti boḷ̌ševistiski - lielā mērā tas tā ir vācu okupācijas dẹl, kas turpinās, un arī tādēḷ, ka turīgie latvieši tādējādi ir noskan,oti apvienot spēkus ar vācbaltiešiem. Šis fakts, iespējams, ir darījis iespējamu latviešus iekḷaut Bermonta jaunajā padomē.

6. Pulkvedis Raiens man nodeva rakstu no Bermonta un vina padomes, tā kopija ir pievienota šim ziņojumam kā 1 . pielikums. ${ }^{21}$

7. Pulkvedis Raiens tāpat nodeva generālim Bērtam protestu no generāla fon der Golca $^{22}$ par attieksmi pret dažiem vāciešiem Liepājā. Šis raksts raisīja zināmas aizdomas, ka fon der Golcam ir plāni attiecībā uz šo pilsētu. ${ }^{23}$

8. Tajā pašā pēcpusdienā man nodeva tulkotu kopiju no 12. oktobrī pārtvertās Bermonta telegrammas Judeničam. ${ }^{24}$ Tajā teikts: ---

\section{$[\ldots]^{25}$}

9. Atvadījušies no pulkveža Raiena, ǵenerālis Bērts un es automašīnā devāmies lejup uz piestātni pie Provodṇika fabrikas, ${ }^{26}$ kur bija sarunāta motorlaiva, kas mūs sagaidīs. Mēs devāmies uz V[iṇa] M[ajestātes] kug̣i Abdiel un tur satikām majoru Kīnenu ${ }^{27}$ un uz brīdi arī kapteini Kērtisu ${ }^{28}$ - v[ecāko] j[ūras] v[irsnieku]. Pamatā mēs ar viņiem apspriedām divus atgadījumus:

10. Zināma nesaprašanās radās no telefoniski nodotās ziṇas, ko majors Grīnsleids ${ }^{29}$ saṇēma no majora Kīnena un kas vēstīja, ka britu kuği aizsargā latviešu labo spārnu un ka tie šaus uz jebkuru lidmašīnu, kas parādīsies redzeslokā, kā arī neļaus karaspēkam pārcelties pāri upei. Mēs no majora Kīnena uzzinājām, ka mīnu kuği iepriekšējā dienā ir nostādīti tā, lai spētu novērot latviešu labo spārnu, taču nekāds noteikts lēmums nav pieņemts par rīcību gadījumā, ja kāda krievu karaspēka daļa mēǵinātu upi pāriet. Es sacīju majoram Kīnenam, ka šādu izkārtojumu grūti nosaukt par "aizsardzību" militārā nozīmē. Ģenerālis Bērts teica, ka viņam uzreiz pēc atgriešanās Rīgā jātiekas ar latviešu virspavēlnieka štāba vadību, lai izskaidrotu kḷūdu. To viņš pēc tam arī izdarīja.

11. Tāpat mēs ar majoru Kīnenu pārrunājām tā rīta incidentu, kura rezultāts bija kapt. Kērtisa lēmums aizvest sabiedroto mīnukugơus lejup pa upi. Šì saruna notika, mums atrodoties uz V[iṇa] M[ajestātes] k[ug̣a] Abdiel klāja, un kapt. Kērtiss, kurš pārraudzijja navigāciju, nebija klāt lielākajā daḷā mūsu sarunu. Es pievienoju kā 2. pielikumu kopiju no raksta par šo incidentu, ko man nākamajā dienā iesniedza militārā misija. ${ }^{30}$ Man un, kā es saprotu, ǵenerālim Bērtam pēc majora Kīnena skaidrojuma škiet, ka barons fon Ronne ${ }^{31}$ tika uzn,emts ar pārmērīgu cieņu, un lēmums aizvest kug̛us lejup pa upi pēc krievu baterijas komandiera ieteikuma, kas dots bez viṇa priekšniecības pavēlēm, jāuzskata par l,oti kaitējošu Lielbritānijas prestižam.

12. Saziṇā ar generāli Bērtu es sastādīju šādu telegrammu, ko v[ecākais] j[ūras] v[irsnieks] apņēmās nosūtīt: --- 
“Šis paredzēts Troopers Astoria ${ }^{32}$ Ārlietu ministrijai no generāla Bērta, pulkveža Talentsa: sekojošā informācija ir ārkārtīgi nepieciešama - (1) Kādus soḷus sabiedrotie spers, atbildot uz Bermonta uzbrukumu, (2) vai viņa spēki tiek uzskatīti par laupītājiem, vai arī tie pārkāpj pamieru, (3) Latvijas valdība, balstoties uz apgalvojumu, ka darbojas sabiedroto vietā, steidzami prasa sākt bombardēšanu no kug̣iem, lai sniegtu morālu atbalstu. Vai šāda atḷauja var tikt dota?"

Mēs nosūtījām šo telegrammu, jo noskaidrojām, ka v[ecākajam] j[ūras] v[irsniekam], līdzīgi kā mums, nav pilnīgi nekādas informācijas par tajā minētajiem jautājumiem, izṇemot to, ka viṇš saṇēmis pavēli ieturēt stingru neitralitāti.

13. 12. oktobra naktī mēs nosūtījām uz kugiem šos virsniekus no politiskās misijas: --Leitn.-komandieris ${ }^{33}$ Stodarts $^{34}$ (kā vecākais)

Hansena kungs (otrais atbildigais)

Berija kungs

Kapt. Brodijs

Malkolma kungs

Elisa kungs

Kapt. Ferovs ${ }^{35}$

Ričardsa kungs

Serž. Vorols

Komandierim Stodartam un Berija kungam tika dots rīkojums pie pirmās iespējas doties pa jūru uz Tallinu, lai nogādātu turp misijas sekcijas atskaites par šo laiku, kapt. Ferovam, kurš bija slims, bija jābūt evakuētam uz Angliju, tiklīdz iespējams, lai vinuu atbrīvotu no šīs misijas dienesta. Misijas dienestā krastā bija atstāti: ---

Pulkvedis-leitn. Talentss

Kapt. Djūhērsts ${ }^{36}$

Kapt. sers Varenders ${ }^{37}$

L. Kolasa kungs ${ }^{38}$

Hempsona kungs

Vilsona kungs

Kapr. Vorens

Studenta ${ }^{39}$ kungs

"Kristofers" (angliski runājošs latvietis)

Tāpat uz kug̣i tika nosūtīti šādi dāṇu un holandiešu pavalstnieki: ---

Dāni

Dž. Makbraida kungs

Holandieši

M. Ragana kungs

Heitbrūka kungs

A. Brauna kungs

F. Herskinda kungs

Bosharta kungs

Speiera kungs

Levī kungs

Matersa kungs

Markusa kungs

Kloda kungs

Vandenberga kungs

Van Mesela kungs

Es ievēroju, ka viens no cilvēkiem, ko dāṇu konsuls ieteica uzṇemt uz kug̣a, bija Baltijas bankas ağents, tāpēc lūdzu majoram Kīnenam pirms kuğu izbraukšanas nodrošināt, lai 
visi šie citu valstu bēgḷi tiktu turēti uz klāja un, ja iespējams, lai tiktu ievērojami aizkavēta viņu ierašanās galamērḳos.

\section{3. oktobrī.}

14. Plkst. 3 naktī majors Grīnsleids pamodināja mani ar telefoniski nodotu ziṇu no majora Kīnena. Tā vēstīja, ka v[ecākais] j[ūras] v[irsnieks] Baltijas jūrā vēlas zināt, vai gadijjumā, ja kuǵi uzsāks bombardēšanu, sabiedroto misijas kāps uz kuǵiem. Es piecēlos un sagatavoju ieteicamo atbildi, ko nosūtīt ar v[ecāko] j[ūras] v[irsnieku] Rīgā, kā arī lūdzu majoram Grīnsleidam ieteikt, lai genenēlis Bērts no rīta piedāvātu šo atbildi franču un amerikāṇu misijām. Galu galā telegramma tika nosūtīta, kā ieteikts sekojošā tekstā, vārdus iekavās pievienojis ǵenerālis Bērts: ---

"Misijas vienprātīgi vēlas bombardēt sabiedrotos, lai morāli iespaidotu latviešus un huṇnuus. ${ }^{40}$ Šī paša mērḳa dēḷ tās uzstāj uz palikšanu Rīgā - uz viṇu pašu atbildību, ja nepieciešams.

(Vai šeit nekavējoties var ierasties jūras virsnieks, lai iegūtu akcijai nepieciešamo detalizēto informāciju[?])"

15. Tajā pašā rītā man tika parādīta kopija no telegrammas, kuru ǵenerālis Bērts un pulkvedis Diparkēêt1 bija nolēmuši nosūtīt uz kug̣iem v[ecākajam] j[ūras] v[irsniekam] Baltijas jūrā. Šìs telegrammas teksts bija šāds: ---

"G̣enerālis Bērts un pulkvedis Diparkē pieprasa Jums nosūtīt Jelgavā un Daugavgrīvā esošo spēku komandierim prasību nekavējoties atvilkt savus lielgabalus un karaspēku no pozīcijām Daugavgrīvā un ap to, jo tas apdraud sabiedroto kuğus, kuriem ir skaidra pavēle palikt upē.

Ja šì prasība netiks izpildīta v[ecākā] j[ūras] v[irsnieka] Rīgā noteiktajā laikā, sabiedroto kuği būs spiesti rīkoties, lai panāktu tās izpildi.

Parakstījis ALFREDS BĒRTS, brig.[ādes] gen.[erālis]

DIPARKĒ, Pulkv.-leitn., Francijas misijas vadītājs"

16. Šorīt es uzzināju, ka ārlietu ministrs Meierovica kungs iepriekšējā naktī devies uz Varšavu.

17. Daudzas personas, briti, dān,i, norvēgì, holandieši, krievi, polii, persieši, čehoslovāki un citu tautību pārstāvji, no rīta apmeklēja misiju, lūdzot dažādu veidu aizsardzību. Tāpēc es apmeklēju ārlietu ministra biedru Albatu ${ }^{42}$ un pēc tam pilsētas komandantu kapt. Dambekalnu, ${ }^{43}$ lai vienotos par pastāvīgu darbības kārtību. Mūsu sakaru virsnieks Studenta kungs saṇēma aț̣auju vest bēgḷu grupas uz piestātni. Mēs apṇēmāmies komandantam katru dienu iesniegt evakuēto sarakstus un informēt komandantu par jebkādiem šaubīgiem gadījumiem, lai noskaidrotu viṇa viedokli. Latviešu varas iestādes no savas puses piekrita, ka es drīkstu evakuēt jebkurus citu valstu pilsoṇus, ja uzskatīšu to par nepieciešamu. Galvenais mērḳis bija nepiel̦aut [Latvijas armijas] dezertieru aizbēgšanu. Tajā pašā vakarā plkst. 7 mēs no piestātnes nosūtījām uz kugíiem šādu grupu: ---

Lašingtona kungs (brits ${ }^{44}$ )

F. Vrankena kungs (beḷgisis)

C. F. Plāta kungs, Plāta kundze \& meita (krievi)

K. Zonnenbergas jaunkundze (latviete)

H. B. Brūna kungs (dānis)

J. F. Jākobsena kungs (holandietis)
Ramzija kungs (brits)

F. Vāgneres jaunkundze (latviete)

V. Endela kungs (holandietis)

V. D. Edisona kungs (brits)

Grejas kundze (krieviete)

Onena kungs (holandietis)

E. Amendes kungs (krievs) 
Katram šīs grupas loceklim bija jāparaksta šāds paziņojums: ---

“Es apzinos, ka uzn,emošā puse nedod uzkāpšanas garantijas, neuzṇemas atbildību par personas un īpašuma drošību, netiek solīts konkrēts galamērķis, un pēc uzkāpšanas uz kuğa nevienam nekādā gadījumā netiks aṭ̣auts nokāpt līdz turpmākam rīkojumam."

18. Apmēram plkst. 3 pēcpusdienā telefona centrāle mani izsauca pie Hjūsa aparāta ${ }^{45}$ uz sarunu ar Tallinu. Izrādījās, ka līnijas otrā galā ir majors Bevens no militārās misijas Tallinā, viņš bija uzaicināts uz sarunu, kura sākotnēji bija paredzēta iepriekšējā dienā. Es sacīju viṇam, ka uzskatu - militārajai misijai Rīgā ir jāzina, kādus ieroču krājumus viṇi nosūta latviešiem. Viņš atbildēja, ka tvaikonis Pyrgos ir tikko ieradies ar visu veidu lielgabaliem, un pirmais vilciens ar krājumu sūtījumu varētu izbraukt no Tallinas 14. oktobra vakarā. Es jautāju, vai nav pienākušas kādas ziņas par sabiedroto reakciju uz Bermonta uzbrukumu, un dabūju atbildi, ka viņi neko nav san,ēmuši.

S. G. Talentss, pulkvedis-leitn.

BRITU KOMISIJAS VADİTĀJS BALTIJAS PROVINCĒS

Avots: National Archives (United Kingdom), Foreign Office, 371/3626/367-375.

Document No. 2

REPORT on events in Riga, from October $14^{\text {th }}$ and $15^{\text {th }}, 1919$

$14^{\text {th }}$ October.

1. I spent some time in helping madame T'Felt, widow of the late Belgian Consul in Riga, in making hurried arrangements for the burial of her husband and for her own embarkation on the "Princess Margaret". Her husband died suddenly early in October, and she had left his body in the mortuary, hoping to transfer it for burial elsewhere. I went with her in the Mission car to make the necessary arrangements with the priest and the cemetery authorities in the morning. I placed our car at her disposal in the afternoon for the funeral, which Sir Victor Warrender attended on my behalf, and in the evening I sent her on board the "Princess Margaret" with her small daughter.

2. Mr Ulmanis was very slightly wounded this morning. A piece of shrapnel appears to have struck his boot and to have caused a contusion upon his leg. This wound should prove of no practical inconvenience and much political advantage to him. I found him in the evening reclining on the sofa and interviewing a local reporter.

In a long private talk after the reporter left, he discussed with me, in optimistic vein, questions of future Government organization in Latvia, especially those connected with the development of Latvian resources. He told me that the Estonians were demanding not only Walk, but the right to occupy the district to the south of Walk, as a condition of their military aid. He had received an indignant telegram from the Lettish residents of Walk. He had also been unfavourably impressed by the conduct of General Pödder and Colonel Reek on their recent informal visit to Riga, which I have already reported. Both these officers got very drunk on that occasion. While hopeful that the Poles would join in the fight against Bermondt, he was afraid that one of the chief inducements to them would be the opportunity for occupying Lithuania, and he told me that the Poles already showed signs of desiring to absorb Libau as a substitute for Dantzig. 
(3) In the course of the day Baron Fircks, President of the Balt National Committee, who is regarded by Mr Ulmanis as having played a proper part during recent weeks, came and during a private conversation gave me various items of information about the Mitau conspiracy, in which a number of his previous associates have taken part. $\mathrm{He}$ mentioned amongst other points that a friend of his had spoken to him of a conversation with General Malcolm in Berlin at the time when the German offers of financial assistance for Bermondt's adventure were becoming prominent. This friend had told Baron Fircks that General Malcolm had given him to understand that England would not object to the employment of German volunteers in Bermondt's advance. He had also suggested to him that English financial support might be obtained. Baron Fircks knew that some of Bermondt's associates had been encouraged to join him by the impression this created that England really supported Bermondt's plans. I report this conversation merely as shoving what I had already gathered from other quarters, viz. that there was some genuine misapprehension, apart from obvious German propaganda, in the views of some of Bermondt's adherents about England's attitude in the matter.

\section{$15^{\text {th }}$ October.}

(4) At 5:30 a.m. the Letts attacked across the main bridge over the Dvina. They went out without wire-cutters or gas helmets, spent some time in trying to pass the German barbed wire defences, and were repulsed with loss. I understand that gas was used against them.

(5) Mr Ulmanis, taking me aside, told me privately this morning that they had decided to replace General Simonsen by Colonel Ballod, who had reluctantly agreed to act as Commander-in-Chief on condition that he could return to take command of the Courland Division when the present operations were over.

(6) The following reply was received to the ultimatum sent by S.N.O. Baltic: ---

"To the British Admiral.

There are not and never have been any German troops in Dünamunde. Request to the Chief of Russian Western Army.

Lt.-General Eberhardt."

In view of this evasive answer, it was decided that the bombardment should proceed. Colonel Alexander an I motored down the right bank of the Dwina and climbed upon the roof of a factory near Neu-Mühlgraben overlooking the mouth, from which we had a birdseye view of the operation. The wind was blowing strongly towards the sea and the noise of bombardment was accordingly muffled, but we could see the flashes of the guns and observed some of the damage done by the bombardment in Dünamunde. After the firing had continued for about half-an-hour, some six Lettish tugs of various sizes put out of a creek between ourselves and the river mouth and, after cruising up and down for a short while, crossed towards Dünamunde. At this point we heard heavy machine-gun fire. This was followed by a bombardment by the ships of the Russian church, which stands prominently over Dünamunde. After this, fire slackened, and we could make out across an intervening tongue of land the Lettish boats advancing up the Aa, apparently stopping to land men at a bend in the river. I was afterwards told by Mr Ulmanis that their men had landed and had taken 500 prisoners, mostly Russians, who thought they were fighting against the Bolsheviks. He told me at about 10:30 the same evening that the troops who had crossed were working their way towards 
Riga without orders, and that Staff had been forced to send supports across the river to Dünamunde.

(7) Mr Ulmanis also told me that the Government were submitting for any comments by the Latvian High Command the text of a proposed reply to the offer of pourparlers sent to them by Bermondt on the second day of the attack. The Cabinet had also decided to send out a short wireless, declaring that all Latvian subjects implicated in Bermondt's conspiracy were traitors, and would forfeit any estates that they possessed in Latvia.

(8) In the afternoon I called on Dr Erhardt, who had arrived from London on the previous day, and had a long talk with him on the subject of future financial arrangements in Latvia.

(9) A good impression has been caused by the announcement that General Yudenich is sending the Letts four guns for use against Bermondt's force.

(10) I have organised a distribution of rations from the supplies belonging to this Mission to British subjects in the town, and in a few cases I have been obliged also to make small advances of money. Most of them had been without food and a few of them were quite destitute. Many of them had been complaining that the British Mission during recent months had done nothing for them. Having regard to the excessively trying times through which all the inhabitants of Riga have passed during recent years, I have not resented these complaints, but hope that the present issues of food will allay them for the future. The "Princess Margaret" brought up with her supplies of repatriated prisoners' rations for their benefit. It has not been so far possible to land them in Riga, but I still hope to get them on shore before she leaves for Copenhagen.

(11) I received a signal last night to the effect that the "Princess Margaret" must leave not later than Friday, with a comment from the captain of H.M.S. Abdiel that she could not maintain water and food supplies. I was told on her arrival that she could accommodate from 300-400 refugees, whereas in fact I have sent on board less than thirty. If, as might easily have happened, I had sent off to her a full complement of passengers, there would apparently have been a commissariat breakdown before she reached Copenhagen. It appears to me under these circumstances that the arrangements for her departure must have been defective.

S.G. Tallents Lt-Colonel

BRITISH COMMISSIONER FOR THE BALTIC PROVINCES

\section{2. dokuments}

ZIN̦OJUMS par notikumiem Rīgā 1919. gada 14. un 15. oktobrī

\section{4. oktobrī.}

1. Es pavadīju kādu laiku, palīdzot T’Feltas kundzei - mirušā Beḷgijas konsula Rīgā atraitnei ${ }^{46}$ - steigšus kārtot viṇas vīra apbedīšanu ${ }^{47}$ un viņas pašas nosūtǐšanu uz [kugơi] "Princess Margaret". Viņas vīrs oktobra sākumā pēkšņi nomira, un viņa bija atstājusi tā ķermeni morgā, cerot nogādāt apbedīšanai kaut kur citur. No rīta misijas automašīnā es devos kopā ar viṇu nokārtot nepieciešamās lietas ar mācītāju un kapsētas administrāciju. Pēcpusdienā es atstāju mūsu automašīnu viṇas rīcībā priekš bērēm, kuras manā vārdā apmeklēja sers Viktors Varenders, un vakarā nosūtīju viṇu uz "Princess Margaret" klāja kopā ar tās mazo meitu. 
2. Šorīt Ulmaṇa kungs tika l̦oti viegli ievainots. Izskatās, ka šrapneḷa šḳemba trāpījusi pa viṇa zābaku un kontuzējusi kāju. Šim ievainojumam nevajadzētu sagādāt viṇam nekādas praktiskas neērtības, taču tas dos daudz politisku priekšrocību. Vakarā es atradu viṇu, atlaidušos dīvānā un sarunājamies ar vietējo reportieri.

Pēc tam, kad reportieris aizgāja, viṇš optimistiskā noskaṇā ilgā privātā sarunā apsprieda ar mani nākotnes valdības organizācijas jautājumus Latvijā, sevišḳi tādus, kas saistīti ar Latvijas resursu attīstību. Viņš man pastāstīja, ka igauṇi pieprasījuši ne tikai Valku, bet arī tiesības okupēt apgabalu dienvidos no Valkas - kā nosacījumu savai militārajai palīdzībai. Viṇš bija saṇēmis sašutuma pilnu telegrammu no Valkas latviešiem. Tāpat viṇu bija nelabvēlīgi noskaņojusi ǵenerāḷa Pedera un pulkveža Rēka uzvedība to nesenās neoficiālās vizītes laikā Rīgā, par kuru es jau esmu ziņojis. Abi šie virsnieki Rīgā bija l̦oti piedzērušies. Optimistiski raudzīdamies uz iespēju, ka poḷi varētu pievienoties cīnaā pret Bermontu, viņš baidījās, ka viens no galvenajiem pamudinājumiem tiem varētu būt izdevība okupēt Lietuvu, un viņš man arī izstāstīja, ka poḷi jau izrāda vēlmi Dancigas vietā iegūt Liepāju.

(3) Dienā barons Firkss, vācbaltiešu Nacionālās komitejas priekšsēdētājs, kuram, pēc Ulmaņa kunga domām, ir bijusi ievērojama loma pēdējo nedēlu laikā, ieradās un privātā sarunā sniedza man dažādu informāciju par Jelgavas sazvērestību, kurā piedalījušies daži no viņa agrākajiem kompanjoniem. Cita starpā viņš minēja, ka viņa draugs ir stāstījis tam par sarunu ar ǵgenerāli Malkolmu ${ }^{48}$ Berlīnē - laikā, kad vācu priekšlikumi par finansiālu atbalstu Bermonta avantūrai sāka kḷut pamanāmi. Šis draugs bija sacījis baronam Firksam, ka ǵenerālis Malkolms licis vinam saprast - Anglijai nevarētu būt iebildumu pret vācu brīvprātīgo iesaistǐšanu Bermonta uzbrukumā. Tāpat viņš bija licis noprast, ka varētu saņemt angḷu finansiālu atbalstu. Barons Firkss zināja, ka dažus no Bermonta atbalstītājiem viņam pievienoties pamudināja radītais iespaids, ka Anglija tiešām atbalsta Bermonta plānus. Es ziņoju par šo sarunu vienīgi tāpēc, lai parādītu, ko jau esmu savācis no citiem avotiem, piemēram, ka dažiem Bermonta piekritējiem bija nepareizs priekšstats par Anglijas attieksmi šajā lietā, un tas neradās vienīgi no skaidri saskatāmas vācu propagandas.

15. oktobrī.

(4) Plkst. 5.30 no rīta latvieši uzbruka pāri Daugavas galvenajam tiltam. Viṇi devās uz priekšu bez dzeloṇdrāšu šḳēēēm un gāzmaskām, kādu laiku pavadīja, mēgeinot pārvarēt vācu dzeloṇ,rāšu aizžogojumus un tika ar zaudējumiem atsisti. Es sapratu, ka pret viniiem izmantota gāze.

(5) Ulmaṇa kungs, šorīt paaicinājis mani sāṇus, privāti izstāstīja, ka viṇi izlēmuši nomainīt ǵenerāli Sīmansonu ar pulkvedi Balodi, kurš negribīgi piekritis darboties kā armijas virspavēlnieks ar nosacījumu, ka viṇš varēs atgriezties Kurzemes divīzijas komandiera amatā, kad pašreizējās operācijas būs pabeigtas.

(6) Uz v[ecākā] j[ūras] v[irsnieka] Baltijas jūrā nosūtīto ultimātu tika saṇemta šāda atbilde: ---

"Britu admirālim. ${ }^{49}$

Daugavgrīvā nav un nekad nav atradies nekāds vācu karaspēks. Vērsieties pie Rietumkrievijas armijas pavēlnieka.

G̦enerālleitn. Eberhards. ${ }^{50 "}$

N̦emot vērā izvairīgo atbildi, tika pien,emts lēmums, ka jāuzsāk bombardēšana. Pulkvedis Aleksanders un es automašīnā devāmies lejup gar Daugavas labo krastu un pie 
Jaunmīlgrāvja uzkāpām uz fabrikas jumta, kas slējās virs ietekas, no tā mēs varējām vērot operāciju no putna skata punkta. Stiprs vējš pūta jūras virzienā, tāpēc bombardēšanas troksnis tika slāpēts, bet mēs varējām redzēt lielgabalu šāvienu uzliesmojumus un dažus postījumus, ko apšaude izraisīja Daugavgrīvā. ${ }^{51}$ Pēc tam, kad apšaude bija turpinājusies apmēram pusstundu, kādi seši dažādu izmēru latviešu velkoṇi izbrauca no grīvas ieloka starp mums un upes ieteku un, īsu brīdi pabraukājuši augšup un lejup pa upi, devās tai pāri uz Daugavgrīvu. Šajā brīdī mēs dzirdējām spēcīgu ložmetēju uguni. Tai sekoja šāvieni no kugóiem pa krievu baznīcu, kas slejas pāri Daugavgrīvai. Pēc tam uguns intensitāte mazinājās un mēs varējām pāri atdalošajai zemes strēlei saskatīt latviešu kug̣īšus, kas tuvojās Lielupei, tie acīmredzot apstājās, lai izsēdinātu karavīrus upes līkumā. Vēlāk Ulmaṇa kungs man teica, ka viṇu karavīri izsēdušies krastā un saṇēmuši gūstā 500 gūstekṇus, galvenokārt krievus, kuri domājuši, ka cīnās pret boḷševikiem. Tajā pašā vakarā ap plkst. 10.30 viņš man sacīja, ka upi pārgājušais karaspēks pats uz savu roku mēgina izlauzties Rīgas virzienā, un štābs bijis spiests nosūtīt pāri upei uz Daugavgrīvu papildspēkus.

(7) Ulmaņa kungs tāpat man izstāstīja, ka Latvijas [armijas] virspavēlniecība iesniegusi valdībai komentēt tekstu ieteicamajai atbildei uz pamiera sarunu piedāvājumu, kas uzbrukuma otrajā dienā saņemts no Bermonta. Kabinets arī izlēmis izsūtīt īsu bezdrāts [telegrammu], tajā paziņojot, ka visi Latvijas pilsoṇi, kas piedalījušies Bermonta sazvērestībā, ir nodevēji un var zaudēt visus īpašumus, kas tiem pieder Latvijā.

(8) Pēcpusdienā es apmeklēju Dr. Erhardu, ${ }^{52}$ kurš iepriekšējā dienā bija atgriezies no Londonas, un mums ar viṇu bija gara saruna par to, kā nākotnē risināt Latvijas finansiālos jautājumus.

(9) Labu iespaidu ir atstājis paziņojums, ka ǵenerālis Judeņičs sūta latviešiem četrus lielgabalus, ko izmantot pret Bermonta spēkiem.

(10) Esmu organizējis [pārtikas] devu izdalǐšanu britu pavalstniekiem pilsētā no šai misijai piederošajiem krājumiem, un dažos gadījumos esmu bijis arī spiests izdalìt nelielus naudas pabalstus. Lielākā dạ̣a no viniiem ir bijuši bez pārtikas, un daži bija pavisam nabadzīgi. Daudzi ir sūdzējušies, ka britu misija pēdējo mēnešu laikā neko nav darījusi vinu labā. N̦emot vērā ārkārtīgi smagos laikus, kādi bija jāiztur visiem Rīgas iedzīvotājiem pēdējos gados, es neņēmu l̦aunā šos pārmetumus, bet ceru, ka pašreizējās pārtikas izdales mazinās tos nākotnē. Kug̣is "Princess Margaret" ir gatavs palīdzēt viṇiem ar saviem repatriējamo karagūstekṇu devu krājumiem. Līdz šim nav bijis iespējams tos izkraut Rīgā, bet es joprojām ceru dabūt tos krastā, pirms kug̣is aizbrauks uz Kopenhāgenu.

(11) Pagājušajā naktī es saṇēmu ziṇu, ka "Princess Margaret" jāizbrauc ne vēlāk kā piektdien, ${ }^{53}$ turklāt V[ina] M[ajestātes] k[uğa] "Abdiel" kapteinis atzīmē, ka "Princess Margaret" pietrūkst ūdens un pārtikas krājumu. Kad kug̣is ieradās, man tika sacīts, ka tas var uzn,emt 300-400 bēgḷus, bet es nosūtīju uz klāja mazāk nekā trīsdesmit. Ja gadījumā, un tas viegli varēja notikt, es būtu nosūtījis uz kug̣i pilnu skaitu pasažieru, uz tā acīmredzot varētu notikt apgādes sistēmas sabrukums, pirms tas sasniegtu Kopenhāgenu. Šajā situācijā man škiet, ka sagatavošanas darbiem pirms kug̣a izbraukšanas bija jābūt slikti veiktiem.

S. G. Talentss, pulkvežleitn.

BRITU KOMISIJAS VADİTĀJS BALTIJAS PROVINCĒS

Avots: National Archives (United Kingdom), Foreign Office, 371/3616/84-88. 


\section{ATSAUCES UN SKAIDROJUMI}

${ }^{1}$ FrīDRIHS ZOMMERS. Bij. studentu bataljona gaitu atcerē. In: Latvijas Kareivis, 09.10.1929., 2. lpp.

${ }^{2}$ Par militārajām norisēm 1919. gada 12.-15. oktobrī sīkāk sk.: MĀRTIN̦š PENIĶIS (red.). Latvijas atbrīvošanas kara vēsture. 2. daḷa. Rīga 1938, 99.-112. lpp.

${ }^{3}$ Stīvens Džordžs Talentss (Stephen George Tallents, 1884-1958), Lielbritānijas valsts ierēdnis, kara laikā - virsnieks. No 1919. gada februāra - politiskās misijas vadītājs Baltijas valstīs.

${ }^{4}$ Bez komentāriem un ar izlaidumiem tie publicēti: ERNEST LLEWELLYN WOODWARD, ROHAN ButLER (eds.). Documents of British Foreign Policy 1919-1939. First Series. Vol. III. 1919. London 1949, pp. 156-162, 174-177.

${ }^{5}$ Dāvids Sīmansons (1859-1933), Krievijas armijas generālmajors, Latvijas armijas generālis. No 1919. gada jūlija līdz 16. oktobrim - Latvijas armijas virspavēlnieks.

${ }^{6}$ Eduards Kalniņš (1876-1964), Krievijas armijas pulkvedis, Latvijas armijas genenerālis. No 1919. gada jūlija līdz 15. oktobrim - Armijas virspavēlnieka štāba priekšnieka vietas izpildītājs.

${ }^{7}$ Alfrēds Bērts (Alfred Burt, 1875-1949), Lielbritānijas armijas genenālmajors, 1919.-1920. gada sākumā - sabiedroto militārās misijas vadītājs Latvijā un Lietuvā.

${ }^{8}$ Kārlis Ulmanis (1877-1942), valstsvīrs, no 1918. līdz 1921. gadam - Latvijas Pagaidu valdības Ministru prezidents.

${ }^{9}$ Zigfrīds Anna Meierovics (1887-1925), valstsvīrs, no 1918. līdz 1924. gadam - Latvijas ārlietu ministrs.

${ }^{10}$ Pāvels Bermonts-Avalovs (Pavel Bermondt-Avalov, 1877-1973), Krievijas armijas štābrotmistrs, 1919. gadā - Rietumkrievijas armijas virspavēlnieks Latvijā un Lietuvā, pulkvedis, ǵenerālmajors.

11 1919. gada 10. oktobrī sabiedrotie Parīzē saistībā ar Bermonta spēku uzbrukumu Rīgai izsludināja pagaidu aizliegumu brīvai Vācijas kug̣u kustībai Baltijas jūrā.

12 Johans Laidoners (Johan Laidoner, 1884-1953), Krievijas armijas pulkvedis, Igaunijas armijas generālis, Igaunijas armijas virspavēlnieks Neatkarības kara laikā.

${ }^{13}$ Ernests Peders (Ernst Põdder, 1879-1932), Krievijas armijas pulkvedis, Igaunijas armijas genenēāis, no 1919. gada maija - 3. divizijas komandieris.

${ }^{14}$ Nikolajs Rēks (īst. v. Nikolajs Bazikovs, 1890-1942), Krievijas armijas virsnieks, Igaunijas armijas pulkvežleitnants, vēlāk ǵenerālleitnants. No 1919. gada septembra - 3. divīzijas štāba priekšnieks.

${ }^{15}$ Edvards Raiens (Edward Ryan, 1883-1923), Amerikas Sarkanā Krusta ārsts, virsnieks (pulkvežleitnants), no 1919. lìdz 1922. gadam - misijas vadītājs Baltijas valstīs.

${ }^{16}$ Tomass Tekerijs Grovs (Thomas Thackeray Grove, 1879-1965), inženieris, Lielbritānijas armijas virsnieks, majors un pagaidu pulkvežleitnants. 1919. gadā dienēja britu militārajā misijā Baltijas valstīs, jūlijā un augustā pildīja jaunizveidotās Latvijas armijas apmācības priekšnieka pienākumus Liepājā, pēc tam līdz oktobra vidum vadīja militārās misijas nodaḷu Jelgavā.

${ }^{17}$ Konstantīns Pālens (1861-1923), Krievijas valsts ierēdnis, hofmeistars (gubernators, Senāta loceklis), muižu īpašnieks Kurzemes guberņā. No 1919. gada 6. oktobra - Jelgavā izveidotās Rietumkrievijas armijas civilpārvaldes (vietējās padomes) priekšsēdētājs.

Teodors Vankins (1873-1947), ārsts, politikis un sabiedriskais darbinieks. No 1919. gada maija līdz jūnijam - Andrieva Niedras provāciskās valdības kara ministrs, rudenī darbojās zemes Bermonta armijas civilpārvaldes - Sevišķās pārvaldes - padomes Pašpārvaldes komitejā.

18 Jānis Čakste (1959-1927), advokāts, valstsvīrs. No 1918. līdz 1920. gadam - Tautas padomes priekšsēdētājs, vēlāk Satversmes sapulces priekšsēdētājs, Valsts prezidents.

${ }^{19}$ Vilhelms fon Firkss (Wilhelm von Fircks, 1870-1933), inženieris, politiḳis, 1919. gadā - Vācbaltiešu nacionālās komitejas priekšsēdētājs. 
${ }^{20}$ Heinrihs fon Brimmers (von Brümmer), vācbaltiešu sabiedriskais darbinieks, 1919. gadā A. Niedras valdības sabiedrisko darbu ministrs un ārlietu ministra vietas izpildītājs.

${ }^{21}$ Netiek publicēts. Sabiedroto pārstāvjiem adresētajā rakstā Bermonts un Pālens skaidro uzbrukuma cēloṇus (Latvijas valdības un armijas darbība), kā arī savas darbības mērḳus.

${ }^{22}$ Rīdigers fon der Golcs (von der Goltz, 1865-1946), Vācijas armijas generālmajors, 1919. gadā 6. rezerves korpusa komandieris Latvijā un Lietuvā.

${ }^{23}$ R. fon der Golcu un Rietumkrievijas armijas vadību interesēja iespēja izmantot Liepājas ostu; rezultātā novembrī sekoja uzbrukums pilsētai, kas tika atsists.

${ }^{24}$ Nikolajs Juden,ičs (Nikolaj Yudenich, 1862-1933), Krievijas armijas infantērijas ǵenerālis, no 1919. līdz 1920. gadam - Krievijas Ziemel̦rietumu armijas virspavēlnieks.

${ }^{25}$ Judeņičs 9. oktobra telegrammā izsludināja Bermontu par nodevēju, un Bermonts, kategoriski noraidīdams visas apsūdzības, šajā telegrammā norādīja, ka sācis uzbrukumu, lai novērstu stāvokli, kādā Judeņičs, kurš nekontrolējot situāciju, nostādījis Ziemel̦rietumu armiju, proti, lai nodrošinātu aizmuguri. Viņš pauda pārliecību, ka uzbrukums palīdzēs arī Ziemeḷrietumu armijai.

${ }^{26}$ 1888. gadā izveidotās krievu-franču gumijas rūpnīcu sabiedrības fabrika "Provodņik" Rīgā atradās pie Sarkandaugavas (Vēlākā Rīgas Elektrorūpnīca).

${ }^{27}$ Ostins (arī Ougustins, Augustine) Henrijs Kīnens (Henry Keenan), Lielbritānijas armijas izlūkdienesta majors, 1919. gada pavasarī - militārās misijas vadìtājs Liepājā un Rīgā, pēc tam tās vadītāja vietnieks.

${ }^{28}$ Berviks Kērtiss (Berwick Curtis, 1876-1965), Lielbritānijas Kara flotes kapteinis, vēlāk viceadmirālis, 1919. gadā - karakuğa Abdiel komandieris.

${ }^{29}$ Sairuss Grīnsleids (Cyrus Greenslade, 1892-1895), Lielbritānijas armijas majors, vēlāk brigādes ǵenerālis, 1919. gadā - militārās misijas loceklis Baltijas valstīs.

${ }^{30}$ Netiek publicēts. Tajā O. Kīnens apraksta franču mīnukuǵa apmeklējumu un pēc tam ierašanos uz kug̣a Abdiel klāja (kopā ar franču virsniekiem), kur Daugavgrīvā novietotās krievu baterijas komandieris fon Ronne lūdza aizvest kuğus drošībā no eventuālās latviešu-krievu artilērijas kaujas lauka.

${ }^{31}$ Fon Ronnes - Kurzemes vācbaltiešu dzimta, iespējams, šeit ir runa par kādu tās pārstāvi.

32 Šifrētais adresāta apzīmējums Lielbritānijas Ārlietu ministrijā.

${ }^{33}$ Leitnants-komandieris - Lielbritānijas Kara flotes dienesta pakāpe.

${ }^{34}$ Henrijs N. Stodarts (Henry N. Stoddart), Lielbritānijas kara flotes virsnieks, politiskās misijas loceklis, kasieris.

${ }^{35}$ Viljams Heistingss Ferovs (William Hastings Farrow, 1893-1946), Lielbritānijas armijas kapteinis, lidotājs, 1919. gadā neilgu laiku atradās dienestā politiskajā misijā Rīgā.

${ }^{36}$ Normens Djūhērsts (Norman Dewhurst, 1887 - pēc 1947), Lielbritānijas armijas kapteinis, politiskās misijas loceklis, vadītāja vietnieks, vēlāk publicists.

${ }^{37}$ Viktors Varenders (Victor Warrender, 1899-1993), Lielbritānijas armijas leitnants, vēlāk politisks darbinieks, 1919. gadā - Lielbritānijas politiskās misijas loceklis Baltijas valstīs.

${ }^{38}$ L. Kolass (L. Collas), Lielbritānijas politiskās misijas civilierēdnis.

${ }^{39}$ Kārlis Students (1885-1964), Krievijas armijas podporučiks, Latvijas armijas virsleitnants, no 1920. gada kapteinis, Ārlietu ministrijas ierēdnis. Pirms Pirmā pasaules kara dzīvojis Anglijā. No 1919. gada 3. jūnija dienējis 1. Atsevišḳās latviešu brigādes štābā, pēc tam Armijas virspavēlnieka štābā, kā angḷu valodas pratējs piekomandēts Lielbritānijas politiskajai misijai.

${ }^{40}$ Huṇni - Āzijas klejotāju tauta, kas agrajos viduslaikos (4.-5. gadsimtā) iebruka Centrāleiropā (gotu zemēs un Romas impērijā), ko līdz savai padzišanai turēja pakḷautībā, aizsākot tautu staigāšanas laikmetu, un dậ̄ji saplūda ar germāṇu ciltīm. Pazīstami ar savu nežēlību. Pirmajā pasaules karā sabiedroto armiju karavīri nicīgi par huṇniem dēvēja vāciešus. 
${ }^{41}$ Emanuels Diparkē (Emmanuel du Parquet, 1869-1933), Francijas armijas pulkvežleitnants, no 1919. līdz 1920. gadam - militārās misijas vadītājs Baltijas valstīs.

${ }^{42}$ Hermanis Albats (1879-1942), Latvijas Ārlietu ministrijas ierēdnis, diplomāts, no 1919. gada augusta līdz septembrim - Konsulārās nodaḷas vadītājs, no septembra - Juridiskā departamenta direktora v. i. un juriskonsults, no 1920. gada jūlija līdz 1923. gadam - ārlietu ministra biedrs.

43 Jānis Dambekalns (1883-1941), virsnieks, policijas ierēdnis, no 1919. gada jūlija - Rīgas Militārās policijas priekšnieks (no 1920. gada - prefekts).

${ }^{44}$ Domāta pilsonība.

${ }^{45}$ Hjūza aparāts: 19. gadsimta 70. gados amerikāņu zinātnieka Deivida Hjūza (Hughes) izgudrots aparāts signālu noraidǐšanai bez vada, 1919. gadā Latvijā to sauca par "bezdrāts telegrāfa aparātu", faktiski runa ir par radiosignālu pārraidīšanu.

${ }^{46}$ Publicētajās atmin̄ās S. Talentss atzīmē, ka atraitne bijusi poliete. STEPHEN TALLENTS. Man and Boy. London 1943, p. 368.

${ }^{47}$ Par it kā 6. oktobrī notikušo Beḷgijas Tirdzniecības ministrijas pārstāvja Rīgā Dizirē T’Felta apbedīšanu katoḷu kapos ar oficiālu Latvijas amatpersonu piedalīšanos Latvijas Preses birojs ziņoja 8. oktobrī, acīmredzot ziña bija pārsteidzīga (5. oktobrī viņa kundze ievietoja presē sludinājumu par nākamajā dienā paredzēto izvadīšanu no morga Antonijas ielā).

${ }^{48}$ Neils Malkolms (Malcolm, 1869-1953), Lielbritānijas armijas generālmajors, no 1919. līdz 1920. gadam - militārās misijas vadītājs Berlīnē.

${ }^{49}$ Domāts Valters Kovans (Cowan, 1871-1956), Lielbritānijas Kara flotes kontradmirālis (no 1927. gada - admirālis), no 1919. gada 6. janvāra - britu Kara flotes spēku Baltijas jūrā komandieris.

${ }^{50}$ Dokumentā sākotnēji kḷūdaini ierakstīts "Ebbert", kas pēc tam ar roku izlabots uz "Ebberhardt", pierakstot jautājuma zīmi. Domāts: Valters fon Eberhards (von Eberhardt, 1862-1944), Vācijas armijas generālmajors. 1919. gada 13. novembrī R. fon der Golcs Jelgavā formāli nodeva viņam savus pienākumus, taču bez sekām; 18. novembrī viņš uzṇēmās jau sakautās Krievijas Ziemeḷrietumu armijas komandēšanu.

${ }^{51}$ Publicētajās atmin̄ās S. Talentss raksta: "[...] Ar lauka binokliem mēs vērojām bombardēšanas sākumu. Mūsu kuǵ̛i no attāluma izskatijjās kā rotallietas; un vējš, kas pūta uz jūru, slāpēja to šāvienu troksni. Taču mēs varējām redzēt lielgabalu uzliesmojumus un dūmus lādiñu sprāgšanas vietās [...]." TALENTS, Man and Boy, p. 368.

${ }^{52}$ Roberts Erhards (Erhardt, 1874-1941), vācbaltiešu sabiedriskais darbinieks, Latvijas valstsvīrs. No 1919. gada 14. jūlija līdz 1920. gada 14. martam - finanšu ministrs.

${ }^{53}$ Domāta piektdiena, 1919. gada 17. oktobris. 